Jurnal Agroteknologi, Vol. 7 No. 1, Agustus 2016: 1 - 6

\title{
PEMBERIAN KOMPOS TKKS DAN COCOPEAT PADA TANAH SUBSOIL ULTISOL TERHADAP PERTUMBUHAN BIBIT KELAPA SAWIT (Elaeis guineensis Jacq.) DI PRE NURSERY
}

\author{
(Composting EFB And Cocopeat On Subsoil Ultisol To The Growth Of Palm Oil Seedlingsin \\ Pre Nursery)
}

SIZIKO ANDRI, NELVIA, SUKEMI INDRA SAPUTRA

Department of Agrotechnology, Faculty of Agriculture, University of Riau Mobile: 08536463 0207, Email: siziko@yahoo.com

\begin{abstract}
Palm oil (Elaeis guineensis Jacq.) is a plantation crop which is quite important in Indonesia because it accounts for foreign exchange and create employment that is high enough. Palm oil empty fruit bunches (EFB) is estimated at $20 \%$ of fresh fruit bunches (FFB) and coco in (cocopeat) are very much in Riau as raw material for fertilizer / compost. Subsoil ultisol a bottom layer of soil with sufficient depth within therefore very potential as a medium of palm oil nursery but has a low fertility signified by the nature of physics, chemistry and biology poor. Organic matter such as EFB compost and cocopeat can improve physical, chemical and biological subsoil ultisol. The research aimed to study the effect of EFB compost, cocopeat and a mixture of both the subsoil ultisol medium on the growth of palm oil seedlings in pre nursery. The study was conducted at the experimental station of Agriculture Faculty of the University of Riau from June to August , 2015. Research conducted an experiment using a completely randomized design (CRD) consisting of 6 treatments (KO : without treatment, $K 1: 100 \mathrm{~g}$ cocopeat, $K 2: 100 \mathrm{~g}$ compost EFB $, K 3: 50 \mathrm{~g}$ compost EFB $+50 \mathrm{~g}$ cocopeat , $\mathrm{K} 4: 75 \mathrm{~g}$ of compost $E F B+25 \mathrm{~g}$ cocopeat and $K 5: 25 \mathrm{~g}$ compost cocopeat $E F B+75 \mathrm{~g}$ per plant) each repeated 4 times. The results showed treament EFB compost $50 \mathrm{~g}$ and cocopeat $50 \mathrm{~g}$ produce in the growth palm oil seedlings better than the other treatments on medium subsoil ultisol in pre nursery.
\end{abstract}

Keywords: palm oil seedlings, Palm oil empty fruit bunches, Cocopeat and Subsoil Ultisols

\section{PENDAHULUAN}

Kelapa sawit (Elaeis guineensis Jacq.) merupakan tanaman perkebunan yang cukup penting di Indonesia karena menyumbang devisa dan menyerap tenaga kerja yang tinggi. Perkebunan kelapa sawit di Riau pada tahun 2013 mencapai 2.399.170 ha dengan tingkat umur yang berbeda. Oleh sebab itu dibutuhkan bibit cukup banyak untuk replanting. Pembibitan kelapa sawit membutuhkan tanah sebagai media yang cukup besar per bibit.

Tanah top soil merupakan tanah yang subur dan ketersediaanya makin berkurang karena terkikis akibat erosi atau penggunaannya yang terus menerus sebagai media pembibitan. Subsoil ultisol dapat menjadi alternatif untuk menggantikan peran top soil sebagai media pembibitan, karena letak lapisannya yang cukup dalam sehingga ketersediannya banyak namun memiliki kesuburan yang rendah. Hidayat, et al., (2007) menyatakan subsoil ultisol merupakan tanah yang miskin unsur hara dan memiliki tingkat kesuburan yang rendah ditandakan dengan $\mathrm{pH}$ berkisar 4,5-5,6 kapasitas tukar kation rendah, $\mathrm{N}$-total rendah, C-organik rendah dan Al-dd yang tinggi.
Pemberian kompos tandan kosong kelapa sawit (TKKS) dan cocopeat diharapkan mampu memperbaiki sifat fisik, kimia dan biologi dari subsoil ultisol. TKKS merupakan bahan organik yang potensial untuk kompos karena tersedia dalam jumlah banyak dan dapat memperbaiki sifat fisik, kimia dan biologi tanah. Ningtyas dan Lia (2010) melaporkan bahwa kompos TKKS mengandung hara makro yaitu 2,15\% $\mathrm{N}$-Total; 1,54\% $\mathrm{P}_{2} \mathrm{O}_{5}$; $0,15 \% \quad \mathrm{~K}_{2} \mathrm{O}$; dengan $\mathrm{pH}\left(\mathrm{H}_{2} \mathrm{O}\right) 6,32$ dan mengandung sedikit unsur mikro seperti $\mathrm{Cu}$, $\mathrm{Zn}, \mathrm{Mn}, \mathrm{Fe}$, Bo, dan Mo. Sedangkan Susanto et al., (2005) melaporkan bahwa unsur hara yang terkandung pada tandan kosong kelapa sawit antara lain 42,8\% C; $0,80 \% \mathrm{~K}_{2} \mathrm{O} ; 2,90 \% \mathrm{~N} ; 0,22 \% \mathrm{P}_{2} \mathrm{O}_{5} ; 0,30 \% \mathrm{Mg}$; 10ppm B; 23ppm Cu; dan 51 ppm Zn.

Selain TKKS, sabut kelapa dalam juga berpotensi sebagai pupuk organik. Serbuk sabut (cocopeat .merupakan bahan organik dari limbah kelapa dalam yang memiliki kandungan unsur hara yang cukup untuk menunjang pertumbuhan tanaman. Agustin (2009) melaporkan cocopeat memiliki $\mathrm{pH}(5,2-$ $6,8)$ dan mengandung $2,91 \% \mathrm{~N} ; 0,08 \% \mathrm{P}$; $0,42 \% \mathrm{~K} ; \quad 0,4 \% \mathrm{Cl} ; 0,01 \% \mathrm{Na}$; dan nisbah $\mathrm{C} / \mathrm{N}$. Bahan organik cocopeat memiliki sifat 
fisik seperti berat jenis; $0,75 \mathrm{~g} / \mathrm{cm}^{3}$, berat volume; $0,13 \mathrm{~g} / \mathrm{cm}^{3}$, dan porositas; $91,9 \%$. Oleh sebab itu pengaruh cocopeat terhadap sifat fisik subsoil ultisol lebih baik dibandingkan kompos TKKS.

Kusuma (2013) melaporkan bahwa pemberian kompos TKKS 20 ton/ha mampu meningkatkan tinggi tanaman, jumlah daun dan diameter bonggol dibandingkan deskripsi standar pertumbuhan bibit kelapa sawit $D X P$ Topas.

Penelitian ini bertujuan untuk mempelajari pemberian kompos TKKS dan cocopeat guna mendapatkan dosis yang tepat pada medium subsoil ultisol terhadap pertumbuhan bibit kelapa sawit di pre nursery.

\section{BAHAN DAN METODE}

Penelitian dilaksanakan di Kebun Percobaan Fakultas Pertanian Universitas Riau pada bulan Juni sampai Agustus 2015. Bahan yang digunakan dalam penelitian adalah kecambah kelapa sawit (Elaeis guineensis Jacq) Varietas Topas 3, kompos TKKS, cocopeat, sub soil ultisol, air, insektisida dan fungisida. Alat yang digunakan adalah cangkul, polybag ukuran 25×25, meteran, jangka sorong, timbangan duduk dan analitik.

Penelitian dilakukan secara eksperimen menggunakan rancangan acak lengkap (RAL) yang terdiri dari 6 perlakuan (Ko: tanpa kompos TKKS dan cocopeat, $\mathrm{K}_{1}$ : $100 \mathrm{~g}$ cocopeat, $\mathrm{K}_{2}: 100 \mathrm{~g}$ kompos TKKS, $\mathrm{K}_{3}$ : $50 \mathrm{~g}$ kompos TKKS $+50 \mathrm{~g}$ cocopeat, $\mathrm{K}_{4}: 75$ $\mathrm{g}$ kompos TKKS $+25 \mathrm{~g}$ cocopeat dan $\mathrm{K}_{5}: 25 \mathrm{~g}$ kompos TKKS + $75 \mathrm{~g}$ cocopeat per tanaman). Masing-masing perlakuan diulang 4 kali, Parameter yang diamati yaitu : tinggi bibit, diameter bonggol, jumlah pelepah daun dan luas daun.

\section{HASIL DAN PEMBAHASAN}

\section{Tinggi Bibit}

Tabel 1 menunjukan bahwa pemberian campuran $50 \mathrm{~g}$ kompos TKKS +50 $\mathrm{g}$ cocopeat per tanaman meningkatkan tinggi bibit kelapa sawit secara nyata dibandingkan dengan tanpa perlakuan $t, 100 \mathrm{~g}$ cocopeat dan $25 \mathrm{~g}$ kompos TKKS + $75 \mathrm{~g}$ cocopeat dan lebih tinngi $8,2 \mathrm{~cm}$ dibandingkan standar PPKS yaitu $20 \mathrm{~cm}$. Hal ini disebabkan pemberian kompos TKKS dan cocopeat pada dosis yang seimbang dapat memperbaiki sifat kimia sehingga meningkatkan ketersediaan hara makro dan mikro serta memperbaiki sifat fisik tanah seperti perbaikan struktur tanah, daya simpan air, pertukaran udara (aerasi tanah) dan kation hara serta meningkatkan peran mikroorganisme tanah, karena kedua bahan organik tersebut mengandung hara lengkap dan memiliki sifat fisik yang baik.

Table 1. Tinggi Bibit Kelapa Sawit Varietas Topas Umur 3 bulan pada Media Subsoil Ultisol dengan Pemberian Campuran Kompos TKKS dan Cocopeat

\begin{tabular}{|c|c|}
\hline $\begin{array}{c}\text { Kompos TKKS + } \\
\text { Cocopeat g/tanaman }\end{array}$ & Tinggi Bibit $(\mathrm{cm})$ \\
\hline $0+0$ & $19,05^{c}$ \\
\hline $0+100$ & $21,88^{\mathrm{c}}$ \\
\hline $100+0$ & $26,10^{a}$ \\
\hline $50+50$ & $28,20^{a}$ \\
\hline $75+25$ & $25,32 a b$ \\
\hline $25+75$ & 22,13 bc \\
\hline
\end{tabular}

Ket : Angka-angka pada jalur yang diikuti oleh huruf kecil yang tidak sama berbeda nyata menurut uji DNMRT pada taraf $5 \%$.

Sutanto et al., (2005) dan Ningtyas dan Lia (2010) melaporkan bahwa kompos TKKS mengandung hara yang lengkap seperti $\mathrm{N}, \mathrm{P}, \mathrm{K}, \mathrm{C}, \mathrm{Mg}, \mathrm{Cu}, \mathrm{Zn}, \mathrm{Mn}, \mathrm{Fe}, \mathrm{Bo}$, dan Mo. Sedangkan Agustin (2009) melaporkan cocopeat memiliki pH $(5,2-6,8)$ dan mengandung $2,91 \% \mathrm{~N} ; 0,08 \% \mathrm{P} ; 0.42 \% \mathrm{~K}$; $0,4 \% \mathrm{Cl} ; 0,01 \% \mathrm{Na}$; nisbah $\mathrm{C} / \mathrm{N} ; 107,4$ dan berat jenis $1,65 \mathrm{~g} / \mathrm{cm}^{3}$, berat volume 0,13 $\mathrm{g} / \mathrm{cm}^{3}$, porositas $91,9 \%$. Menurut Gunawan dan Winata (2007) bahan organik cocopeat memiliki struktur gabus halus yang sulit terurai di dalam tanah namun memberikan keuntungan dalam menyerap dan mempertahankan air.

Menurut Nainggolan (2011), pertumbuhan tanaman yang normal diperoleh bila ketersedian hara yang cukup dan seimbang di dalam tanah. Kemampuan tanah dalam menyediakan unsur hara bagi tanaman merupakan faktor utama dalam pertumbuhan dan produksi tanaman (Soepadi, 2001). Ketersediaan hara yang cukup dalam tanah akan memberikan pengaruh terhadap pertambahan tinggi tanaman.

$$
\text { Valentino (2014) melaporkan }
$$

pemberian $50 \mathrm{~g}$ kompos TKKS dan $50 \mathrm{~g}$ asam humat per tanaman pada subsoil ultisol di main nursery menghasilkan tinggi bibit kelapa sawit sebesar $22,30 \mathrm{~cm}$ sedangkan dengan tanpa perlakuan hanya $13,40 \mathrm{~cm}$.

Tabel 1. menunjukkan bahwa tanpa kompos TKKS dan cocopeat menghasilkan tinggi bibit kelapa sawit yang paling rendah yaitu $19,05 \mathrm{~cm}$. Hal ini disebabkan tidak tersedianya hara yang cukup dan lengkap serta sifat fisik subsoil ultisol yang kurang baik sehingga menyebabkan pertumbuhan tanaman terhambat. Hidayat, et al., (2007) menyatakan subsoil ultisol merupakan tanah yang miskin unsur hara dan memiliki tingkat kesuburan yang rendah ditandakan dengan $\mathrm{pH}$ 
berkisar 4,5-5,6 kapasitas tukar kation rendah, $\mathrm{N}$-total rendah, C-organik rendah dan Al-dd yang tinggi.

\section{Jumlah Pelepah Daun}

Tabel 2. menunjukan bahwa pemberian $100 \mathrm{~g}$ kompos TKKS, $\quad 50 \mathrm{~g}$ kompos TKKS + $50 \mathrm{~g}$ cocopeat dan $75 \mathrm{~g}$ kompos TKKS + $25 \mathrm{~g}$ cocopeat meningkatkan jumlah pelepah daun bibit kelapa sawit secara nyata dibandingkan dengan tanpa perlakuan atau pemberian $100 \mathrm{~g}$ cocopeat . Hal ini sejalan dengan perbaikan sifat kimia dan fisik tanah karena penambahan kompos TKKS dan cocopeat.

Perbaikan sifat kimia akan meningkatkan ketersediaan hara lengkap (makro dan mikro) serta perbaikan fisik tanah akan meningkatkan serapan hara dan air oleh akar tanaman. Peningkatan serapan hara dan air akan memacu proses fotosintesis dan metabolisme tanaman sehingga terbentuknya senyawa-senyawa yang berperan penting dalam proses pertumbuhan tanaman. Sebagai contoh protein, peningkatan jumlah protein akan meningkatkan jumlah sel yang berarti meningkatkan pertumbuhan tanaman, salah satunya jumlah pelepah daun.

Tabel 2. Jumlah Pelepah Daun Kelapa Sawit Varietas Topas Umur 3 Bulan pada Media Suboil Ultisol dengan Pemberian Campuran Kompos TKKS dan Cocopeat

\begin{tabular}{ll}
\hline \multicolumn{1}{c}{$\begin{array}{c}\text { Kompos TKKS }+ \\
\text { Cocopeat g/tanaman }\end{array}$} & $\begin{array}{c}\text { Jumlah Pelepah Daun } \\
\text { (helai) }\end{array}$ \\
\hline $0+0$ & $3,37^{\mathrm{c}}$ \\
$0+100$ & $3,62^{\mathrm{bc}}$ \\
$100+0$ & $4,12^{\mathrm{a}}$ \\
$50+50$ & $4,25^{\mathrm{a}}$ \\
$75+25$ & $4,00^{\mathrm{a}}$ \\
$25+75$ & $3,87^{\mathrm{ab}}$ \\
\hline
\end{tabular}

Ket : Angka-angka pada jalur yang diikuti oleh huruf kecil yang tidak sama berbeda nyata menurut uji DNMRT pada taraf $5 \%$.

$$
\text { Pakpahan (2008) melaporkan }
$$

pemberian $50 \mathrm{~g}$ kompos TKKS pada topsoil inceptisol di main nursery menghasilkan jumlah pelepah bibit kelapa sawit 6,66 helai jika dibandingkan dengan tanpa pemberian kompos TKKS hanya menghasilkan 4,16 helai.

Peningkatan jumlah pelepah daun bibit kelapa sawit tidak lepas kaitannya dengan pertambahan tinggi (Tabel 1.). Peningkatan tinggi bibit kelapa sawit juga akan berpengaruh terhadap jumlah pelepah daun. Hidajat (1994), menyatakan bahwa pembentukan daun berkaitan dengan tinggi tanaman, dimana tinggi tanaman dipengaruhi oleh tinggi batang. Semakin tinggi batang maka buku dan ruas semakin banyak sehingga jumlah daun meningkat.
Peningkatan jumlah pelepah daun juga disebabkan oleh genetik tanaman itu sendiri. Gardner et al; (1991) menyatakan bahwa proses pertumbuhan dan perkembangan daun dipengaruhi oleh faktor genetik dari tanaman itu sendiri sehingga dapat mempengaruhi jumlah daun, selain itu ketersediaan unsur hara juga dapat mempengaruhinya.

\section{Luas Daun}

Tabel 3. menunjukan bahwa pemberian $75 \mathrm{~g}$ kompos TKKS $+25 \mathrm{~g}$ cocopeat menghasilkan luas daun bibit kelapa sawit tertinggi namun peningkatannya tidak nyata dengan pemberian $100 \mathrm{~g}$ kompos TKKS dan $50 \mathrm{~g}$ kompos TKKS + $50 \mathrm{~g}$ cocopeat tetapi berbeda nyata dengan tanpa perlakuan, $100 \mathrm{~g}$ cocopeat dan $25 \mathrm{~g}$ kompos TKKS $+75 \mathrm{~g}$ cocopeat. Pemberian kompos TKKS dan cocopeat dapat memperbaiki sifat kimia tanah sehingga meningkatkan ketersediaan hara dan meningkatkan serapan hara oleh akar tanaman.

Unsur $\mathrm{C}, \mathrm{H}, \mathrm{O}, \mathrm{N}$ dan $\mathrm{Mg}$ berperan dalam pembentukan klorofil yang berguna dalam proses fotosintesis. Fotosintat hasil fotosintesis akan dimetabolisme menjadi berbagai senyawa organik yang berperan dalam pembentukan sel sehingga terjadi pertambahan luas daun.

Tabel 3. Luas Daun Bibit Kelapa Sawit Varietas Topas Umur 3 Bulan pada Media Subsoil Ultisol dengan Pemberian Campuran Kompos TKKS dan Cocopeat

\begin{tabular}{lc}
\hline $\begin{array}{c}\text { Kompos TKKS }+ \\
\text { Cocopeat g/tanaman }\end{array}$ & Luas Daun $\left(\mathrm{cm}^{2}\right)$ \\
\hline $0+0$ & $32,92^{\mathrm{b}}$ \\
$0+100$ & $38,00^{\mathrm{b}}$ \\
$100+0$ & $56,26^{\mathrm{a}}$ \\
$50+50$ & $56,13^{\mathrm{a}}$ \\
$75+25$ & $58,77^{\mathrm{a}}$ \\
$25+75$ & $40,27^{\mathrm{b}}$ \\
\hline
\end{tabular}

Angka-angka pada jalur yang diikuti oleh huruf kecil yang tidak sama berbeda nyata menurut uji DNMRT pada taraf $5 \%$.

Kompos TKKS mengandung unsur hara seperti unsur $\mathrm{N}, \mathrm{P}$ dan $\mathrm{Mg}$ yang cukup untuk pertumbuhan tanaman dimana unsur $\mathrm{N}$ dan $P$ membantu proses pembelahan dan pembesaran sel yang menyebabkan daun muda lebih cepat mencapai bentuk sempurna. Hal ini sesuai dengan pendapat Lakitan (2000) yang menyatakan bahwa ketersediaan unsur $\mathrm{N}$ dan $\mathrm{P}$ akan mempengaruhi daun dalam hal bentuk dan jumlah.

Unsur $\mathrm{N}$ dan $\mathrm{Mg}$ berperan dalam proses fotosintesis bila proses fotosintesis meningkat maka akan menghasilkan 
karbohidrat dan senyawa-senyawa lainnya yang digunakan tanaman untuk pertumbuhannya, salah satunya pertumbuhan luas daun tanaman.

\section{Diameter Bonggol}

Tabel 4. menunjukan pemberian $50 \mathrm{~g}$ kompos TKKS + $50 \mathrm{~g}$ cocopeat cenderung meningkatkan diameter bonggol bibit kelapa sawit dibandingkan dengan perlakuan lainnya dan sudah mendekati standar pertumbuhan diameter boggol PPKS $(1,3 \mathrm{~cm})$. Hal ini dikarenakan pertumbuhan diameter bonggol kelapa sawit lebih lambat dibandingkan pertumbuhan diameter lainnya (tinggi bibit, jumlah pelepah daun dan luas daun).

Tabel 4. Diameter Bonggol Bibit Kelapa Sawit Varietas Topas Umur 3 Bulan pada Media Subsoil Ultisol dengan Pemberian Campuran Kompos TKKS dan Cocopeat

\begin{tabular}{lc}
\hline $\begin{array}{c}\text { Kompos TKKS }+ \\
\text { Cocopeat g/tanaman }\end{array}$ & Diameter Bonggol $(\mathrm{cm})$ \\
\hline $0+0$ & $1,09^{\mathrm{a}}$ \\
$0+100$ & $1,22^{\mathrm{a}}$ \\
$100+0$ & $1,24^{\mathrm{a}}$ \\
$50+50$ & $1,25^{\mathrm{a}}$ \\
$75+25$ & $1,24^{\mathrm{a}}$ \\
$25+75$ & $1,16^{\mathrm{a}}$ \\
\hline
\end{tabular}

Ket : Angka-angka pada lajur yang diikuti huruf kecil yang sama berbeda tidak nyata menurut uji DNMRT pada taraf $5 \%$

$$
\text { Pakpahan (2008) melaporkan }
$$

pemberian $50 \mathrm{~g}$ kompos TKKS pada topsoil inceptisol di main nursery menghasilkan diameter bonggol bibit kelapa sawit sebesar $2,14 \mathrm{~cm}$ dan tidak nyata dibandingkan tanpa pemberian kompos TKKS yaitu 2,11 cm.

Pembesaran diameter bonggol dipengaruhi oleh ketersediaan unsur $\mathrm{K}$ dalam tanah. Unsur $\mathrm{K}$ berperan mempercepat pertumbuhan jaringan meristematik terutama pada batang tanaman, menguatkan batang sehingga tidak mudah rebah.

Menurut Leiwakabessy (1988) unsur K sangat berperan dalam meningkatkan diameter batang tanaman, khususnya dalam peranannya sebagai jaringan yang menghubungkan antara akar dan daun, kekurangan unsur $\mathrm{K}$ dapat menghambat proses pembesaran lingkar batang. Unsur $\mathrm{K}$ yang terkandung dalam kompos TKKS yaitu $0,80 \% \mathrm{~K}$ dan dalam cocopeat mengandung $0,42 \% \mathrm{~K}$.

\section{KESIMPULAN DAN SARAN}

\section{Kesimpulan}

Pemberian kompos TKKS dan cocopeat dengan dosis $50 \mathrm{~g}$ TKKS dan $50 \mathrm{~g}$ cocopeat menghasilkan pertumbuhan bibit kelapa sawit yang baik di pre nursery pada medium subsoil ultisol dibandingkan dengan tanpa pemberian kompos TKKS dan cocopeat. Pemberian kompos TKKS dan cocopeat tidak berpengaruh nyata terhadap pertumbuhan diameter bonggol bibit kelapa sawit pada medium subsoil ultisol. Hal ini dikarenakan pertumbuhan diameter bonggol kelapa sawit lebih lambat dibandingkan pertumbuhan parameter laiannya (tinggi bibit, jumlah pelepah daun dan luas daun).

\section{Saran}

Untuk mendapatkan pertumbuhan bibit kelapa sawit yang baik di pre nursery pada medium subsoil ultisol adalah dengan pemberian kompos TKKS dan cocopeat dengan dosis dosis $50 \mathrm{~g}$ TKKS dan $50 \mathrm{~g}$ cocopeat.

\section{DAFTAR PUSTAKA}

Agustin Leizy Free.2010. Pemanfaatan Kompos Sabut Kelapa dan Zeolit sebagai Campuran Tanah untuk Media Pertumbuhan Bibit Kakao pada Beberapa Tingkat Ketersediaan Air. Skripsi Fakultas Pertanian, Universitas Jember, Jember, Indonesia.

Gardner P. F., Pearee BR., Mitchell L. R.,1991. Fisiologi Tanaman Budidaya. UI press. Jakarta.

Gunawan dan Winata. 2007. Budidaya Anggrek. Jakarta. Penebar Swadaya.

Hidajat, E. B. 1994. Morfologi Tumbuhan. Departemen Pendidikan dan Kebudayaan Direktorat Jenderal Pendidikan Tinggi Proyek Pendidikan Tenaga Kerja.

Kusuma, Hadi. 2013. Pemberian kompos tandan kosong kelapa sawit rotasi kedua dan ZPT alami di medium Subsoil Ultisol terhadap pertumbuhan bibit kelapa sawit (Elaeis guineensis Jacq). Skripsi Fakultas Pertanian Universitas Riau.

Lakitan, B. 2005.Fisiologi Pertumbuhan dan Perkembangan Tanaman.PT. Raja Grafindo Persada. Jakarta

Leiwakabessy, F. M. 1998. Kesuburan Tanah. Pertanian IPB. Bogor.

Nainggolan, D. 2011. Pengaruh penyemprotan $\mathrm{Zn}$, Fe, dan B pada daun tanaman jagung (Zea mays L) yang ditanam diareal pengendapan tailing. Skripsi sarjana pertanian fapertek unipa (tidak dipublikasikan)

Ningtyas, V. A. dan Lia, Y. A. 2010.Pemanfaatan tandan kosong kelapa sawit sisa media jamur merah 
(Volvarella volvaceae) sebagai pupuk organik dengan penambahan aktivator Effective Microorganisme EM-4.Skripsi. Fakultas Teknik Kimia. Institut Teknologi Surabaya. Surabaya.

Pakpahan Herwin. 2008. Aplikasi Kompos Tandan Kosong Kelapa Sawit (Elaeis guineensis Jacq) Terhadap Pertumbuhan Bibit Kelapa Sawit Di Pembibitan Utama.Skripsi Fakultas Pertanian Universitas Riau.

Pusat Penelitian Kelapa Sawit (PPKS). 2005. Pembibitan Kelapa Sawit. Medan.

Soepardi, G. 2001. Sifat dan ciri-ciri Tanah. Departemen IImu Tanah, Fakultas Pertanian, Institut Pertanian Bogor.

Sutanto A., A.E. Prasetyo, Fahroidayanti, A.F. Lubis, dan A.P. Dongoran. 2005. Viabilitas bioaktivator jamur trichoderma koningii pada media tandan kosong kelapa sawit. Jurnal Penelitian Tandan Kelapa Sawit. Volume 13(1) : 25-33.

Valentino Sembiring Janrico. 2015. Pertumbuhan Bibit Kelapa Sawit (Elaeis guineensis Jacq.) Di Pembibitan Utama Pada Medium Sub Soil Ultisol Yang Diberi Asam Humat Dan Kompos Tandan Kosong Kelapa Sawit.Skripsi Fakultas Pertanian Universitas Riau. 
Pemberian Kompos TKKS dan Cocopeat Pada Tanah Subsoil (Siziko Andri, et al.) 


\section{$\mathbf{J}$

PEMBERIAN KOMPOS TKKS DAN COCOPEAT PADA TANAH SUBSOIL ULTISOL TERHADAP PERTUMBUHAN BIBIT KELAPA SAWIT (Elaeis guineensis Jacq.) DI PRE NURSERY

Composting EFB And Cocopeat On Subsoil Ultisol To The Growth Of Palm Oil Seedlingsin Pre Nursery

Siziko Andri, Nelvia, Sukemi Indra Saputra

PENGARUH INOKULASI CAMPURAN ISOLAT BAKTERI PELARUT FOSFAT INDIGENUS RIAU TERHADAP PERTUMBUHAN DAN PRODUKSI TANAMAN KEDELAI (Glycine max L. Merr)

Effect of Riau Indigenus Phosphate Solubilizing Bacteria Isolate Mixture Inoculation on Soybean Growth and Yield

Lufita Nur Alfiah, Delita Zul, Nelvia

PROPAGASI IN VITRO ANGGREK (Dendrobium phalaenopsis Fitzg) TERHADAP PEMBERIAN HORMON IBA DAN KINETIN

In Vitro Propagation of Orchid (Dendrobium phalaenopsis Fitzg) on The Addition Iba and Kinetion Hormones

Imam Mahadi

PEMBERIAN BEBERAPA AMELIORAN TERHADAP PERUBAHAN SIFAT KIMIA TANAH GAMBUT

Giving Some Ameliorants To Changes Chemical Properties of Peat Soil

Ervina Aryanti, Yulita, Aulia Rani Annisava

ANALISIS PEMASARAN PADI SAWAH DI KECAMATAN RAMBAH SAMO KABUPATEN ROKAN HULU

Marketing Analysis Of Paddy Field In The Rambah Samo District Rokan Hulu Regency

Darus

KEANEKARAGAMAN SERANGGA PADA TUMPANGSARI TANAMAN PANGAN SEBAGAI TANAMAN SELA DI PERTANAMAN KELAPA SAWIT BELUM MENGHASILKAN Insect Diversity on Intercropping System in Young Palm Oil

Lutfi Arifin, Mokhammad Irfan, Indah Permanasari, Auli Rani Annisava, dan A. Taufiq Arminudin ....... 